\title{
Salen-Aluminum Complexes as Host Materials for Red Phosphorescent Organic Light-Emitting Diodes
}

\author{
Hye Jin Bae, Kyu Young Hwang, Min Hyung Lee, ${ }^{\dagger, *}$ and Youngkyu Do* \\ Department of Chemistry, KAIST, Daejeon 305-701, Korea. *E-mail: ykdo@kaist.ac.kr \\ ${ }^{\dagger}$ Department of Chemistry and Energy Harvest-Storage Research Center, University of Ulsan, Ulsan 680-749, Korea \\ *E-mail:lmh74@ulsan.ac.kr \\ Received June 11, 2011, Accepted July 20, 2011
}

\begin{abstract}
The properties of monomeric and dimeric salen-aluminum complexes, [salen $\left.\left(3,5-{ }^{t} \mathrm{Bu}\right)_{2} \mathrm{Al}(\mathrm{OR})\right], \mathrm{R}=\mathrm{OC}_{6} \mathrm{H}_{4-}$ $p-\mathrm{C}_{6} \mathrm{H}_{6}(\mathbf{H 1})$ and $\mathrm{R}=\left[\operatorname{salen}\left(3,5-{ }^{t} \mathrm{Bu}\right) \mathrm{AlOPh}\right] \mathrm{C}\left(\mathrm{CH}_{3}\right)_{2}(\mathbf{H 2})$ (salen $=N, N^{\prime}$-bis-(salicylidene)-ethylenediamine) as host layer materials in red phosphorescent organic light-emitting diodes (PhOLEDs) were investigated. H1 and $\mathbf{H 2}$ exhibit high thermal stability with decomposition temperature of 330 and $370{ }^{\circ} \mathrm{C}$. DSC analyses showed that the complexes form amorphous glasses upon cooling of melt samples with glass transition temperatures of 112 and $172^{\circ} \mathrm{C}$. The HOMO $(c a .-5.2 \sim-5.3 \mathrm{eV})$ and LUMO $(c a .-2.3 \sim-2.4 \mathrm{eV})$ levels with a triplet energy of $c a .1 .92 \mathrm{eV}$ suggest that $\mathbf{H 1}$ and $\mathbf{H 2}$ are suitable for a host material for red emitters. The PhOLED devices based on $\mathbf{H 1}$ and $\mathbf{H} 2$ doped with a red emitter, $\operatorname{Ir}(\mathrm{btp})_{2}$ (acac) (btp = bis(2-(2'-benzothienyl)pyridinato-N, $\mathrm{C}^{3}$; acac $=$ acetylacetonate) were fabricated by vacuum-deposition and solution process, respectively. The device based on vacuum-deposited $\mathbf{H 1}$ host displays high device performances in terms of brightness, luminous and quantum efficiencies comparable to those of the device based on a CBP $(4,4$ '-bis $(N$ carbazolyl)biphenyl) host while the solution-processed device with $\mathbf{H} 2$ host shows poor performance.
\end{abstract}

Key Words : Salen-aluminum complex, Host materials, Red phosphorescence, OLEDs

\section{Introduction}

Organic light-emitting devices with phosphorescent emitters doped into host materials (PhOLEDs) have been extensively investigated due to their high internal quantum efficiency up to $100 \%$ of a theoretical value from contribution of both singlet and triplet excitons for light-emission. ${ }^{1-7}$ Phosphorescent emitters doped into host materials are also found to reduce saturation of emissive sites and triplet-triplet annihilation. Along with heavy metal complexes which constitute the majority of phosphorescent emitters in PhOLEDs due to their high quantum efficiency, the selection of a proper host material is also regarded as important to achieve high efficiency in PhOLEDs. The host materials for PhOLEDs should possess higher triplet energy than guest materials to prevent reverse energy transfer from the guest to the host and high thermal stability to form stable amorphous films.

$4,4^{\prime}$-Bis $\left(N\right.$-carbazolyl)biphenyl $(\mathrm{CBP})^{8,9}$ is one of the popular host materials in the PhOLED reported so far. Despite its high efficiency in green PhOLEDs, however, CBP host utilized in red PhOLEDs has often caused low efficiencies and high driving voltages ${ }^{10}$ mainly owing to the poor matching of energy levels between CBP and adjacent hole- and electron-transporting layers, resulting in deep charge trapping in the emitting layer. ${ }^{11-13}$ To circumvent this problem, novel host materials based on organometallic complexes have been reported in red PhOLEDs. For example, zinc complex supported by bis[2-(2-benzothiazoyl)phenolate ligand showed improved driving voltage, efficiency, and device lifetime. ${ }^{14}$ We have recently demonstrated that the penta-coordinated salen-Al complexes $\left(\right.$ salen $=N, N^{\prime}$-bis(salicylidene)-ethylenediamine) can be used as good holeblocking materials ${ }^{15}$ as well as emitting layer materials ${ }^{16}$ in OLEDs. Particularly, we have found that salen-Al moiety can act as a host in the dopant assembly OLEDs based on heterodinuclear $\mathrm{Al} / \mathrm{Ir}$ complex through efficient energy transfer from the salen-Al moiety to the Ir(III) emitter. ${ }^{17}$ These versatile uses of salen-Al complexes as layer materials in OLEDs could be mainly attributable to their proper HOMO and LUMO energy levels (ca. -5.4 and $-2.3 \mathrm{eV}$ ), high thermal stability, and high PL efficiency. In a continuous effort to utilize the salen-Al complexes in OLEDs, we have set out to investigate whether the salen-Al complexes could act as host materials in red PhOLEDs.

In this report, monomeric $\left[\operatorname{salen}\left(3,5-{ }^{t} \mathrm{Bu}\right)_{2} \mathrm{Al}(\mathrm{OR})\right], \mathrm{R}=$ $\mathrm{C}_{6} \mathrm{H}_{4}-p-\mathrm{C}_{6} \mathrm{H}_{6}(\mathbf{H 1})$ and dimeric $\left[\operatorname{salen}\left(3,5-{ }^{t} \mathrm{Bu}\right)_{2} \mathrm{Al}(\mathrm{OR})\right], \mathrm{R}$
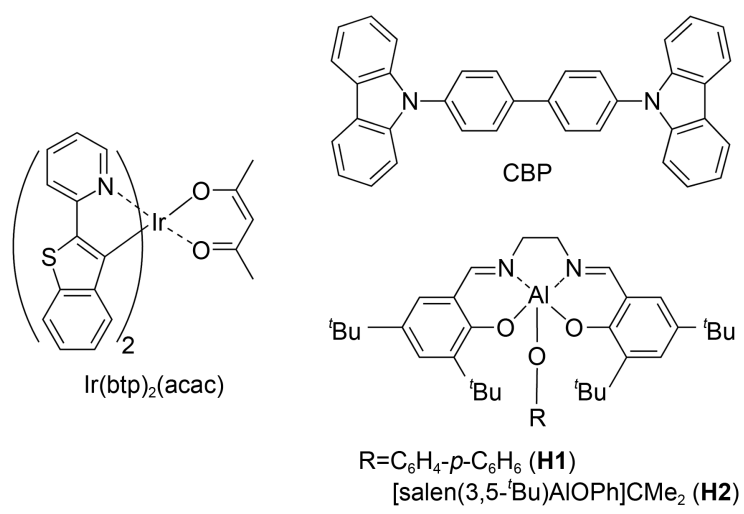

Chart 1 
$=\left[\operatorname{salen}\left(3,5-{ }^{\mathrm{t}} \mathrm{Bu}\right) \mathrm{AlOPh}\right] \mathrm{C}\left(\mathrm{CH}_{3}\right)_{2}(\mathbf{H} 2)$ were investigated as host materials for red PhOLEDs. A device fabricated with H1 host by vacuum deposition in combination with $\operatorname{Ir}(\mathrm{btp})_{2}$ (acac) (btp = bis (2-(2'-benzothienyl)-pyridinato-N, $\left.\mathrm{C}^{3}\right)$; acac $=$ acetylacetonate $)^{7}$ as a red emitter shows improved maximum current efficiency of $32.15 \mathrm{~cd} \cdot \mathrm{A}^{-1}$ when compared with the reference device based on CBP host. Particularly, since solution processed PhOLEDs are advantageous in terms of easy and low-cost scalable process, ${ }^{18-21} \mathbf{H 2}$ host was utilized as host material for a solution-processed red phosphorescent device. Details of synthesis, characterization, and utilization of $\mathbf{H 1}$ and $\mathbf{H 2}$ as host materials in red PhOLEDs are described.

\section{Experimental Section}

General Considerations. All operations were performed under an inert nitrogen atmosphere using standard Schlenk and glove box techniques. Anhydrous grade solvents (Aldrich) were dried by passing through an activated alumina column and stored over activated molecular sieves (5 Å). Spectrophotometric-grade chloroform was used as received from Aldrich. Commercial reagents were used without any further purification after purchasing from Aldrich (3,5-Di-tertbutyl-2-hydroxybenzaldehyde, ethylenediamine, trimethylaluminum (2.0 M solution in toluene), 4-phenylphenol, bisphenol A. H1 was prepared according to the previously reported procedures by our group. ${ }^{15,16} \mathrm{CDCl}_{3}$ from Cambridge Isotope Laboratories was used after drying over activated molecular sieves (5 $\AA$ ). NMR spectra of compounds were recorded on a Bruker Avance 400 spectrometer (400.13 $\mathrm{MHz}$ for ${ }^{1} \mathrm{H}, 100.62 \mathrm{MHz}$ for ${ }^{13} \mathrm{C}$ ) at ambient temperature. Chemical shifts are given in ppm, and are referenced against external $\mathrm{Me}_{4} \mathrm{Si}\left({ }^{1} \mathrm{H},{ }^{13} \mathrm{C}\right)$. Elemental analyses were performed on an EA1110 (FISONS Instruments) by the Environmental Analysis Laboratory at KAIST. Thermogravimetric analyses (TGA) were carried out under a nitrogen atmosphere at a heating rate of $10{ }^{\circ} \mathrm{C} / \mathrm{min}$ with a Dupont 9900 Analyzer. The melting transition $\left(T_{\mathrm{m}}\right)$ and glass transition $\left(T_{\mathrm{g}}\right)$ temperatures were measured by differential scanning calorimetry (DSC, TA Instrument Q100) at heating and cooling rates of $10{ }^{\circ} \mathrm{C} \cdot \mathrm{min}^{-1}$. UV-vis and emission spectra were recorded on a Jasco V-530 and a Spex Fluorog-3 Luminescence spectrophotometer, respectively, in $\mathrm{CHCl}_{3}$ solvent with a $1-\mathrm{cm}$ quartz cuvette at ambient temperature. Cyclic voltammetry experiment was performed using an AUTOLAB/PGSTAT12 system.

Synthesis of $\left[\left(3,5-\mathrm{Di}-{ }^{-} \mathrm{Bu}\right)\right.$ salenAlOPh ${ }_{2} \mathrm{C}\left(\mathrm{CH}_{3}\right)_{2}(\mathrm{H} 2)$. A solution of $\left(3,5-\mathrm{di}-{ }^{\mathrm{t}} \mathrm{Bu}\right)_{2}$ salen $(2.0 \mathrm{mmol})$ in $30 \mathrm{~mL}$ of toluene was treated with 1.1 equiv of trimethylaluminum $(1.1 \mathrm{~mL})$ at $-78^{\circ} \mathrm{C}$. The reaction mixture was slowly allowed to warm to room temperature and then refluxed for $1 \mathrm{~h}$. After cooling to ambient temperature, the solvent was removed under reduced pressure. Washing with $n$-hexane followed by drying in vacuo afforded the Al precursors (P1). Next, the solution of bisphenol A $(0.25 \mathrm{~g}, 0.5 \mathrm{mmol})$ in 10 $\mathrm{mL}$ of toluene was added to the solution of P1 $(1 \mathrm{mmol})$ in
$20 \mathrm{~mL}$ of toluene via cannula. The reaction mixture was refluxed at $110^{\circ} \mathrm{C}$ for $4 \mathrm{~h}$. After cooling, the yellow precipitate was filtered off, washed with $\mathrm{Et}_{2} \mathrm{O}$ and $n$-hexane, and finally dried in vacuum. Yield: $72 \%$. ${ }^{1} \mathrm{H}$ NMR $\left(\mathrm{CDCl}_{3}\right)$ : $\delta 8.29(\mathrm{~s}, 4 \mathrm{H}), 7.49$ (d, $J=2.6 \mathrm{~Hz}, 4 \mathrm{H}), 6.97$ (d, $J=2.5 \mathrm{~Hz}$, $4 \mathrm{H}), 6.58(\mathrm{~d}, J=8.6 \mathrm{~Hz}, 4 \mathrm{H}), 6.18(\mathrm{~d}, J=8.6 \mathrm{~Hz}, 4 \mathrm{H}), 3.97$ $(\mathrm{m}, 4 \mathrm{H}), 3.63(\mathrm{~m}, 4 \mathrm{H}), 1.46(\mathrm{~s}, 36 \mathrm{H}), 1.32(\mathrm{~s}, 6 \mathrm{H}), 1.28(\mathrm{~s}$, 36H). ${ }^{13} \mathrm{C} \mathrm{NMR}\left(\mathrm{CDCl}_{3}\right): \delta 169.85,163.39,157.68,140.97$, $139.84,138.18,130.76,126.98,126.83,118.61,118.35$, 54.95, 40.98, 35.57, 33.97, 31.37, 31.17, 29.73. Anal. Calcd for $\mathrm{C}_{79} \mathrm{H}_{106} \mathrm{Al}_{2} \mathrm{~N}_{4} \mathrm{O}_{6}$ : $\mathrm{C}, 75.21 ; \mathrm{H}, 8.47 ; \mathrm{N}, 4$ 4.44. Found $\mathrm{C}$ $76.04, \mathrm{H} 8.63, \mathrm{~N} 4.62$. TGA: $T_{\mathrm{d} 5}=481^{\circ} \mathrm{C}$. DSC: $T_{\mathrm{m}}=275$ ${ }^{\circ} \mathrm{C}, T_{\mathrm{g}}=172{ }^{\circ} \mathrm{C}$.

Cyclic Voltammetry. Cyclic voltammetry measurements were carried out with a three-electrode cell configuration consisting of platinum working and counter electrodes and a $\mathrm{Ag} / \mathrm{AgNO}_{3}(0.1 \mathrm{M}$ in acetonitrile) reference electrode at room temperature. The solvent was acetonitrile and $0.1 \mathrm{M}$ tetrabutylammonium hexafluorophosphate was used as the supporting electrolyte. The oxidation potentials were recorded at a scan rate of $50 \mathrm{mV} \cdot \mathrm{s}^{-1}$ and reported with reference to the ferrocene/ferrocenium $\left(\mathrm{Fc} / \mathrm{Fc}^{+}\right)$redox couple.

Fabrication of Electroluminescence Devices. EL devices $\mathbf{A}$ and $\mathbf{B}$ having the following configurations were fabricated: ITO/NPB/H1 or $\mathbf{C B P}$ : $\operatorname{Ir}(\mathrm{btp})_{2}(\mathrm{acac}) / \mathrm{BCP} / \mathrm{Alq}_{3} / \mathrm{LiF} /$ Al. The OLEDs were fabricated by thermal evaporation onto a cleaned glass substrate precoated with indium tin oxide (ITO) without breaking the vacuum. Prior to organic layer deposition, the ITO substrates were exposed to UV-ozone flux for $20 \mathrm{~min}$ following degreasing in isoprophylalcohol. NPB (40 nm), H1 or CBP:Ir(btp) 2 (acac) $(8 \mathrm{wt} \%, 30 \mathrm{~nm})$, BCP $(10 \mathrm{~nm}), \operatorname{Alq}_{3}(40 \mathrm{~nm}), \operatorname{LiF}(1 \mathrm{~nm}), \mathrm{Al}(100 \mathrm{~nm})$ were grown by thermal evaporation at the base pressure of $<5 \times 10^{-7}$ torr (deposition rates: NPB, BCP, $\mathrm{Alq}_{3}=1 \AA / \mathrm{s}$, $\mathrm{LiF}=0.1 \AA / \mathrm{s}, \mathrm{Al}$ electrode $=3 \AA / \mathrm{s})$. All the materials were purified using train sublimation before use. EL devices $\mathbf{C}$ having the following configurations were fabricated: ITO/ PEDOT:PSS/H2:Ir(btp) $)_{2}(\mathrm{acac}) / \mathrm{BCP} / \mathrm{Alq}_{3} / \mathrm{LiF} / \mathrm{Al}$. PEDOT used as a hole-injection layer was spin-coated onto precleaned ITO (60 min baking at $\left.120{ }^{\circ} \mathrm{C}\right)$. EML (H2 and $\left.\operatorname{Ir}(\mathrm{btp})_{2}(\mathrm{acac})\right)$ was fabricated by spin coating from a 1,2 dichloroethane solution at the rate of 2,500 rpm, which was then subjected to baking at $80^{\circ} \mathrm{C}$ for $30 \mathrm{~min}$. The film thickness of the EML was determined with a TENCOR alpha-step 500 profiler and was estimated to be $30 \mathrm{~nm}$. BCP $(20 \mathrm{~nm}), \mathrm{Alq}_{3}(30 \mathrm{~nm}), \mathrm{LiF}(1 \mathrm{~nm})$, and $\mathrm{Al}(100 \mathrm{~nm})$ were successively deposited on top of the EML using the vacuum evaporation method under vacuum $\left(\sim 7 \times 10^{-7}\right.$ torr) (deposition rate: $\mathrm{BCP}, \mathrm{Alq}_{3}=1 \AA / \mathrm{s}, \mathrm{LiF}=0.11 \AA / \mathrm{s}, \mathrm{Al}$ electrode $=3$ $\AA / s)$. EL spectra were obtained with a PR-650 spectrometer. Current-voltage and luminance-voltage characteristics were recorded on a current-voltage source (Keithley 237) and a luminescence detector (PR-650).

\section{Results and Discussion}

Synthesis and Characterization. The synthetic route to 


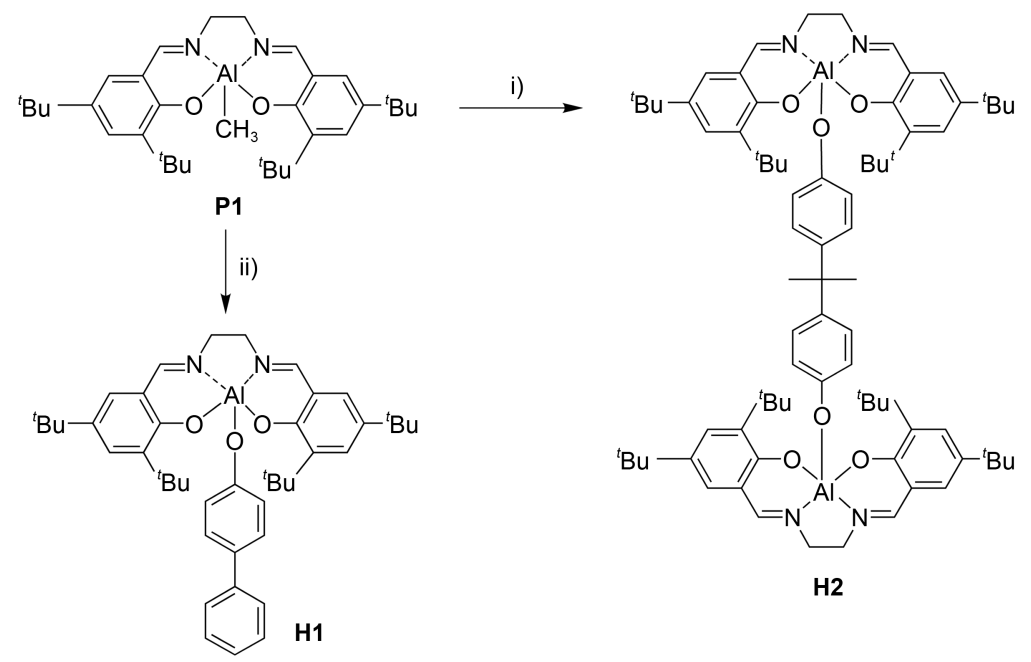

Scheme 1. Synthesis of H1 and H2. Reaction conditions: i) 4-phenylphenol, reflux, 4 h/toluene, 79\%; ii) bisphenol A, reflux, 4 h/toluene, $72 \%$.

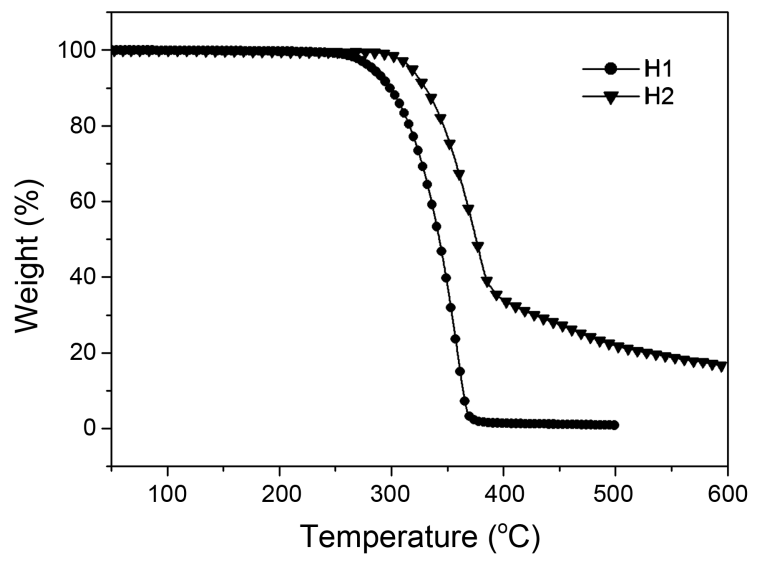

Figure 1. TGA curves of $\mathbf{H 1}$ and $\mathbf{H 2}$.

the salen-Al complexes $\mathbf{H 1}$ and $\mathbf{H} \mathbf{2}$ is shown in Scheme 1. The preparation of $\mathbf{H 1}$ was followed by the procedure reported previously by us ${ }^{15,16}$ and $\mathbf{H 2}$ was also analogously synthesized by the reaction of salen-Al precursor and bisphenol $A$ in a 2:1 molar ratio. H2 was obtained as airstable yellow powder in good yield $(72 \%)$. The formation of H2 has been confirmed by ${ }^{1} \mathrm{H}$ and ${ }^{13} \mathrm{C}$ NMR spectroscopy and elemental analysis.

The thermal properties of the complexes were investigated by thermogravimetric analysis (TGA) and differential scanning calorimetry (DSC). Both complexes exhibit high $T_{\mathrm{d} 5}$ of 330 and $371{ }^{\circ} \mathrm{C}$, respectively, (Figure 1) and have high glass transition temperature $\left(T_{\mathrm{g}}\right)$ of 112 and $172{ }^{\circ} \mathrm{C}$ (Figure 2$)$ that are much higher than that of $\mathrm{CBP}\left(62^{\circ} \mathrm{C}\right) .{ }^{22}$ The high thermal stability of $\mathbf{H 1}$ and $\mathbf{H 2}$ appears to be originated from both the steric protection of the Al-center by tert-butyl groups and the penta-coordinate bonding nature around the $\mathrm{Al}$ center. The higher $T_{\mathrm{d}}$ and $T_{\mathrm{g}}$ values of dimeric $\mathbf{H 2}$ than those of $\mathbf{H 1}$ and other monomeric salen-Al complexes ${ }^{16}$ is in accordance with the steric bulkiness of $\mathbf{H} 2$ that can restrict molecular motion. Particularly, both complexes form amorphous glasses upon cooling of melt samples, which was also confirmed by

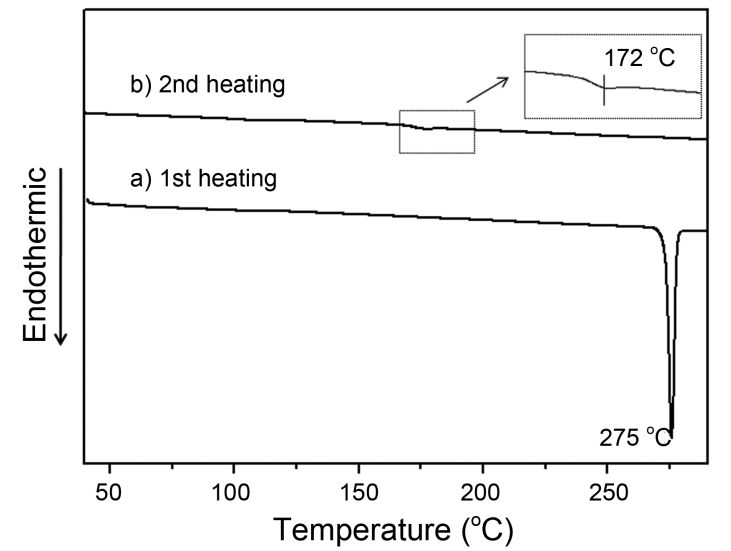

Figure 2. (a) The first and (b) second heating DSC curves of $\mathbf{H 2}$ at $10{ }^{\circ} \mathrm{C} / \mathrm{min}$.

the absence of melting transitions in the second heating DSC curve, pointing to good film forming capability and thus reduction of the possibility of phase separation upon heating. $^{23,24}$

The optical properties of $\mathbf{H 1}$ and $\mathbf{H} \mathbf{2}$ were investigated by means of UV-vis absorption and photoluminescence (PL) spectroscopy (Figure 3 and Table 1). H1 and H2 exhibit almost the same absorption features with maximum absorption around at $364 \mathrm{~nm}$ attributable to $\pi-\pi^{*}$ transitions of salen-moiety. ${ }^{16,26}$ The identical emission features are also observed with the same maximum emission wavelength around at $480 \mathrm{~nm}$. The similar optical properties of $\mathbf{H 1}$ and $\mathbf{H 2}$ indicate that the salen-Al fragments of $\mathbf{H 2}$ are electronically isolated due to the absence of $\pi$ conjugation via bisphenol A bridging ligand.

The HOMO and LUMO energy levels of $\mathbf{H 1}$ and $\mathbf{H 2}$ were estimated from the optical band gaps and oxidation onset potentials measured by UV-vis absorption and cyclic voltammetry (CV). The HOMO and LUMO energy levels and hence the band gap $\left(E_{\mathrm{g}}=2.9 \mathrm{eV}\right)$ of both complexes are found to be similar as listed in Table 1. The HOMO levels of 
Table 1. Optical, electrochemical, and thermal data for $\mathbf{H 1}$ and $\mathbf{H 2}$

\begin{tabular}{|c|c|c|c|c|c|c|c|}
\hline & $\begin{array}{c}\lambda_{\text {abs }}(\mathrm{nm}) \\
(\log \varepsilon)^{a}\end{array}$ & $\begin{array}{c}\lambda_{\mathrm{em}} / \mathrm{nm} \\
(\eta)^{a, b}\end{array}$ & $\begin{array}{l}\mathrm{HOMO} \\
(\mathrm{eV})^{c}\end{array}$ & $\begin{array}{c}\text { LUMO } \\
(\mathrm{eV})\end{array}$ & $\begin{array}{c}E_{\mathrm{T}} \\
(\mathrm{eV})^{d}\end{array}$ & $\begin{array}{c}T_{\mathrm{d}} \\
\left({ }^{\circ} \mathrm{C}\right)^{e}\end{array}$ & $\begin{array}{c}T_{\mathrm{g}} \\
\left({ }^{\circ} \mathrm{C}\right)^{f}\end{array}$ \\
\hline 1 & $\begin{array}{c}364 \\
(4.04)\end{array}$ & $\begin{array}{c}480 \\
(0.31)\end{array}$ & -5.3 & -2.4 & 1.92 & 330 & 112 \\
\hline $\mathbf{H 2}$ & $\begin{array}{c}363 \\
(4.30)\end{array}$ & $\begin{array}{c}481 \\
(0.31)\end{array}$ & & & 1.92 & 371 & 172 \\
\hline
\end{tabular}

${ }^{a} \mathrm{CHCl}_{3}$ solution. $\left(1.0 \times 10^{-5} \mathrm{M}\right) .{ }^{b} \eta_{\text {rel }}$ is the relative PL efficiency with respect to that $(0.55)$ of quinine sulfate. ${ }^{25}{ }^{c} \mathrm{HOMO}$ energy levels were determined from the oxidation potentials measured by cyclic voltammetry in $\mathrm{CH}_{2} \mathrm{Cl}_{2} .{ }^{d}$ Triplet energy level from a phosphorescence peak measured at $77 \mathrm{~K}$. ${ }^{e}$ At a heating rate of $10{ }^{\circ} \mathrm{C} \cdot \mathrm{min}^{-1}$ under $\mathrm{N}_{2} \cdot{ }^{f}$ At heating and cooling rates of $10^{\circ} \mathrm{C} \cdot \mathrm{min}^{-1}$.

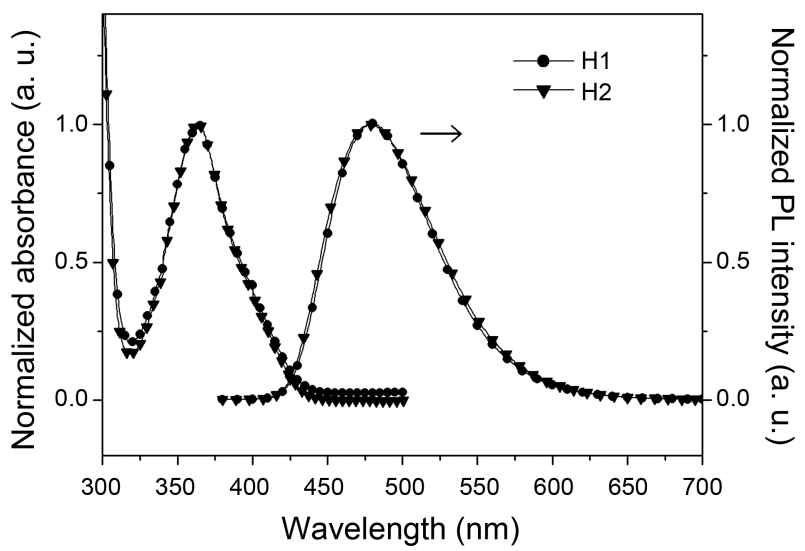

Figure 3. UV-vis absorption and emission spectra of $\mathbf{H 1}$ and $\mathbf{H} \mathbf{2}$ in $\mathrm{CHCl}_{3}$ solution $\left(1.0 \times 10^{-5} \mathrm{M}\right)$.

$\mathbf{H 1}$ and $\mathbf{H 2}$ ( -5.3 and $-5.2 \mathrm{eV}$, respectively) are closer to that of NPB ( $N, N^{\prime}$-bis(naphthalene-1-yl)- $N, N^{\prime}$-bis(phenyl)-benzidine) hole-transporting material $(\mathrm{ca} .-5.4 \mathrm{eV})^{28}$ than that of CBP $(c a .-6.0 \mathrm{eV})$. Thus, the hole injection from an NPB layer into an salen-Al host could be more facile than the injection into a CBP. Since the $E_{\mathrm{g}}$ values $(2.9 \mathrm{eV})$ of $\mathbf{H 1}$ and $\mathbf{H 2}$ are smaller than that of $\mathrm{CBP}^{27}(3.1 \mathrm{eV})$, it is also expected that OLED devices with $\mathbf{H 1}$ and $\mathbf{H} \mathbf{2}$ as a host may prevent deep charge trapping in the emitting layer. Being consistent with this result, the triplet energy levels $\left(E_{\mathrm{T}}\right)$ of both complexes are estimated to be about $1.92 \mathrm{eV}$, which is well matched with that of red phosphorescent $\operatorname{Ir}(\mathrm{btp})_{2}(\mathrm{acac})$ $\left(E_{\mathrm{T}}=2.0 \mathrm{eV}\right) .{ }^{29}$ Comparison with the high $E_{\mathrm{T}}$ of CBP $(c a$. $2.56 \mathrm{eV})^{4}$ indicates that the triplet energy transfer from $\mathbf{H 1}$ and $\mathbf{H} 2$ host to the red dopant could occur much effectively.

OLED Performance. In order to test the host capability of $\mathbf{H 1}$ and H2, red PhOLED devices (devices A-C) were fabricated and their performances were evaluated. Device A which adopts $\mathbf{H 1}$ as a host was fabricated by vacuum deposition. Device $\mathbf{B}$ with a CBP host was also compared as a reference device of $\mathbf{H 1}$ host. Devices $\mathbf{A}$ and $\mathbf{B}$ have been constructed in the following configuration: ITO/NPB (40 $\mathrm{nm}) / \mathbf{A}$ or $\mathbf{B}: \operatorname{Ir}(\mathrm{btp})_{2}(\mathrm{acac})(8 \mathrm{wt} \%, 30 \mathrm{~nm}) / \mathrm{BCP}(10 \mathrm{~nm}) /$ $\mathrm{Alq}_{3}(40 \mathrm{~nm}) / \mathrm{LiF}(1 \mathrm{~nm}) / \mathrm{Al}(100 \mathrm{~nm})(\mathrm{BCP}=$ bathocuproine, $\mathrm{Alq}_{3}=\operatorname{tris}(8$-hydroxyquinolinolato)aluminium). In the case of device $\mathbf{C}$ with $\mathbf{H 2}$ host, the hole-injection and active layers were constructed by spin-coating: ITO/PEDOT:PSS

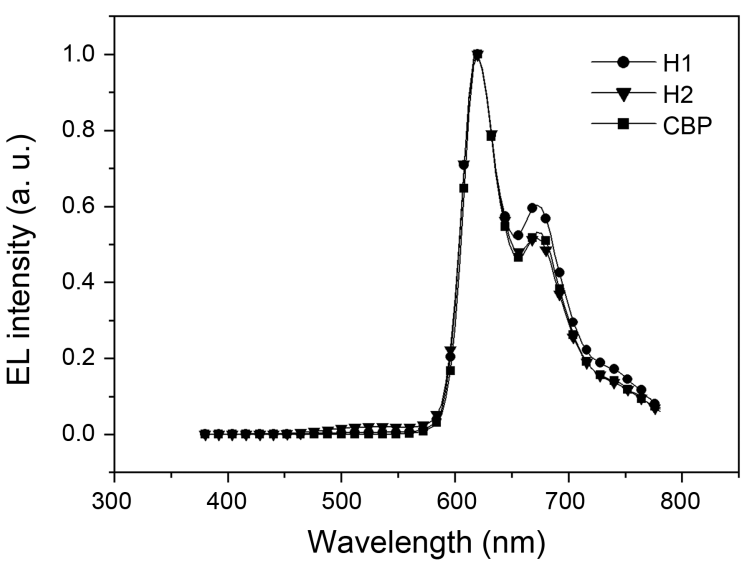

Figure 4. EL spectra of devices A-C incorporating H1, CBP, and $\mathbf{H 2}$ as a host material, respectively.

$(40 \mathrm{~nm}) / \mathbf{C}: \operatorname{Ir}(\mathrm{btp})_{2}(\mathrm{acac})(12 \mathrm{wt} \%, 30 \mathrm{~nm}) / \mathrm{BCP}(20 \mathrm{~nm}) /$ $\mathrm{Alq}_{3}(30 \mathrm{~nm}) / \mathrm{LiF}(1 \mathrm{~nm}) / \mathrm{Al}(100 \mathrm{~nm})(\mathrm{PEDOT}: \mathrm{PSS}=$ poly(3,4-ethylenedioxythiophene):poly(styrenesulfonate)).

As shown in Figure 4, all the devices A-C emitted an almost same red light typical of $\operatorname{Ir}(\mathrm{btp})_{2}(\mathrm{acac})$-based OLEDs featuring the electroluminescence (EL) spectra with an emission maximum $\lambda_{\mathrm{em}}$ of $620 \mathrm{~nm}$ (CIE coordinates of $\mathrm{x}=$ $0.67, y=0.32$ for devices $\mathbf{A}$ and $\mathbf{B}$ and $\mathrm{x}=0.66, \mathrm{y}=0.33$ for device $\mathbf{C}$ ). This result indicates that $\mathbf{H 1}$ and $\mathbf{H 2}$ properly function as host materials for the red emission of $\operatorname{Ir}(\mathrm{btp})_{2}-$ (acac). Moreover, the absence of any emission from H1 and $\mathbf{H} 2$ host materials in the devices $\mathbf{A}$ and $\mathbf{C}$ indicates the complete energy transfer from $\mathbf{H 1}$ and $\mathbf{H} \mathbf{2}$ host to $\operatorname{Ir}(\mathrm{btp})_{2}$ (acac). According to the luminous efficiency-current densityluminance characteristics of devices shown in Figure 5, device $\mathbf{A}$ with $\mathbf{H 1}$ host exhibits a maximum luminous efficiency $\left(\eta_{\mathrm{L}}\right)$ of $32.15 \mathrm{~cd} \cdot \mathrm{A}^{-1}$ which is higher than that of device $\mathbf{B}$ with CBP host $\left(21.15 \mathrm{~cd} \cdot \mathrm{A}^{-1}\right)$. At the luminance of $100 \mathrm{~cd} \cdot \mathrm{m}^{-2}$, the luminous efficiency of device $\mathbf{A}\left(7.26 \mathrm{~cd} \cdot \mathrm{A}^{-1}\right)$ is also higher than that of device $\mathbf{B}\left(7.0 \mathrm{~cd} \cdot \mathrm{A}^{-1}\right)$. Furthermore, the overall high external quantum efficiency ( $\left.\eta_{\mathrm{EQE}}\right)$ is also observed for device $\mathbf{A}\left(\max . \eta_{\mathrm{EQE}}=8.59 \%\right)$ in a wide range of current density although it is somewhat lower than that for device B (Figure 6). The high performance of device

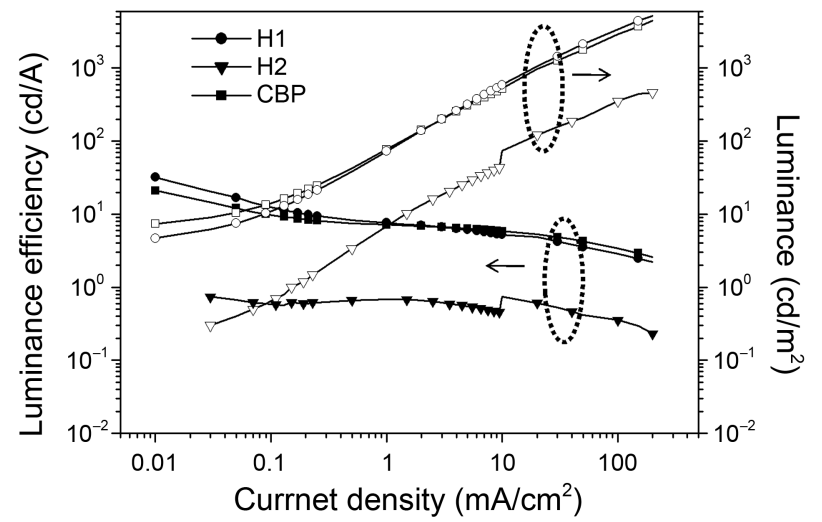

Figure 5. Luminous efficiency-current density-luminance characteristics for devices A-C. 


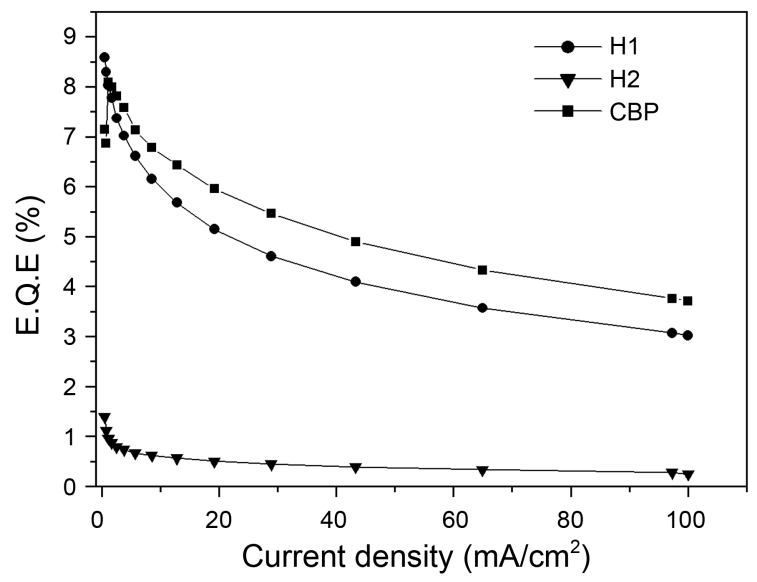

Figure 6. External quantum efficiency-current density characteristics for devices A-C.

A with $\mathbf{H 1}$ host could be related to the proper $E_{\mathrm{T}}$ as well as HOMO and LUMO levels of $\mathbf{H 1}$ for red phosphorescent emitter. On the other hand, device $\mathbf{C}$ with $\mathbf{H} 2$ host shows a maximum luminous efficiency of $0.737 \mathrm{~cd} \cdot \mathrm{A}^{-1}$ and a maximum external quantum efficiency of $1.39 \%$, all of which however are much lower than those of devices $\mathbf{A}$ and B. These results indicate that the spin-coated $\mathbf{H} 2$ complex can function as host materials for red emission, but the overall performance is poorer than those of devices fabricated by vacuum deposition.

In summary, we have demonstrated that salen-aluminum complexes possess a relatively narrow band gap and high thermal stability that are suitable for host material in red PhOLEDs. The PhOLED devices based on salen-aluminum complexes doped with $\operatorname{Ir}(\text { btp })_{2}($ acac $)$ can be fabricated by both vacuum-deposition and solution process. The vacuumdeposited device containing monomeric H1 host display high device performances in terms of brightness and luminous and external quantum efficiencies comparable to those of the CBP-based device. However, the solution-processed device based on dimeric $\mathbf{H} \mathbf{2}$ host showed poor device performances.

Acknowledgments. Financial supports from the National Research Foundation of Korea (No. 2010-0008264 for Y. Do and No. 2010-0007796 for M.H. Lee) and the Priority Research Centers Program of the NRF (No. 2009-0093818 for M.H. Lee) is gratefully acknowledged. We would like to thank Dongwoo Fine-Chem Co. for assisting with the EL measurements.

\section{References}

1. Baldo, M. A.; O’Brien, D. F.; You Y.; Shoustikov, A.; Sibley, S.; Thompson, M. E.; Forrest, S. R. Nature (London) 1998, 395, 151.

2. Wong, W.-Y.; Ho, C.-L.; Gao, Z.-Q.; Mi, B.-X.; Chen, C.-H.;
Cheah, K.-W.; Lin, Z. Angew. Chem. Int. Ed. 2006, 45, 7800.

3. Ikai, M.; Tokito, S.; Sakamoto, Y.; Suzuki, T.; Taga, Y. Appl. Phys. Lett. 2001, 79, 156.

4. Adachi, C.; Kwong, Djurovich, R. P.; Adamovich, V.; Baldo, M. A.; Thompson, M. E.; Forrest, S. R. Appl. Phys. Lett. 2001, 79, 2082.

5. Kwong, R. C.; Nugent, M. R.; Michalski, L.; Ngo, T.; Rajan, K.; Tung, Y.-J.; Weaver, M. S.; Zhou, T. X.; Hack, M.; Thompson, M. E.; Forrest, S. R.; Brown, J. J. Appl. Phys. Lett. 2002, 81, 162.

6. Ren, X.; Li, J.; Holmes, R. J.; Djurovich, P. I.; Forrest, S. R.; Thompson, M. E. Chem. Mater. 2004, 16, 4743.

7. Lamansky, S.; Djurovich, P.; Murphy, D.; Abdel-Razzaq, F.; Lee, H.-E.; Adachi, C.; Burrows, P. E.; Forrest, S. R.; Thompson, M. E. J. Am. Chem. Soc. 2001, 123, 4304.

8. O’Brien, D. F.; Baldo, M. A.; Thompson, M. E.; Forrest, S. R Appl. Phys. Lett. 1999, 74, 442.

9. Baldo, M. A.; Lamansky, S.; Burrows, P. E.; Thompson, M. E.; Forrest, S. R. Appl. Phys. Lett. 1999,75, 4.

10. Adachi, C.; Baldo, M. A.; Forrest, S. R.; Lamansky, S. L.; Thomapson, M. E.; Kwong, R. C. Appl. Phys. Lett. 2001, 78, 1622.

11. Tsuzuki, T.; Tokito, S. Adv. Mater. 2007, 90, 276.

12. Jeon, W.-S.; Park, T.-J.; Park, J.-J.; Pode, R.; Jang, J.; Kwon, J.-H. Org. Electron. 2009, 10, 240.

13. Gong, X.; Ostrowski, J. C.; Moses, D.; Bazan, G. C.; Heeger, A. J. Adv. Funct. Mat. 2003, 13, 439 .

14. Kanno, H.; Ishikawa, K.; Nishio, Y.; Endo, A.; Adachi, C.; Shibata, K. Appl. Phys. Lett. 2007, 90, 123509.

15. Hwang, K. Y.; Lee, M. H.; Jang, H.; Sung, Y.; Lee, J. S.; Kim, S. H.; Do, Y. Dalton Trans. 2008, 1818.

16. Hwang, K. Y.; Kim, H.; Lee, Y. S; Lee, M. H.; Do, Y. Chem. Eur. J. 2009, 15, 6478 .

17. Huh, J. O.; Lee, M. H.; Jang, H.; Hwang, K. Y.; Lee, J. S.; Kim, S. H.; Do, Y. Inorg. Chem. 2008, 47, 6566.

18. Ho, C.-L.; Wong, W.-Y.; Gao, Z.-Q.; Chen, C.-H.; Cheah, K.-W.; Yao, B.; Xie, Z. Y.; Wang, Q.; Ma, D. G.; Wang, L. X.; Yu, X.-M.; Kwok, H.-S.; Lin, Z. Y. Adv. Funct. Mater. 2008, 18, 319.

19. Ge, Z. Y.; Hayakawa, T.; Ando, S.; Ueda, M.; Akiike, T.; Miyamoto, H.; Kajita, T.; Kakimoto, M. Adv. Funct. Mater. 2008, 18, 584.

20. Rehmann, N.; Hertel, D.; Meerholz, K.; Becker, H.; Heun, S. Appl. Phys. Lett. 2007, 91, 103507.

21. Hou, L. D.; Duan, L.; Qiao, J.; Li, W.; Zhang, D. Q.; Qiu, Y. Appl. Phys. Lett. 2008, 92, 263301.

22. Tsai, M.-H.; Hong, Y.-H.; Chang, C.-H.; Su, H.-C.; Wu, C.-C.; Matoliukstyte, A.; Simokaitiene, J.; Grigalevicius, S.; Grazulevicius, J. V.; Hsu, C.-P. Adv. Mater. 2007, 19, 862.

23. Santerre, F.; Bedjia, I.; Dodelet, J. P. Chem. Mater. 2001, 13, 1739. (b) Liou, G.-S.; Hsiao, S.-H.; Chen, W.-C.; Yen, H. J. Macromolecules 2006, 39, 6036.

24. Cozzi, P. G.; Dolci, L. S.; Garelli, A.; Montalti, M.; Prodi, L.; Zaccheroni, N. New J. Chem. 2003, 27, 692.

25. Melhuish, W. H. J. Phys. Chem. 1961, 65, 229.

26. Jegier, J. A.; Muñoz-Hernández, M.-Á.; Atwood, D. A. J. Chem. Soc., Dalton Trans. 1999, 2583.

27. Gao, Z. Q.; Mi, B. X.; Tam, H. L.; Cheah, K. W.; Chen, C. H.; Wong, M. S.; Lee, S. T.; Lee, C. S. Adv. Mater. 2008, 20, 774.

28. Tseng, R. J.; Chiechi, R. C.; Wudl, F.; Yang, Y. Appl. Phys. Lett. 2006, 88,093512

29. Sudhakar, M.; Djurovich, P. I.; Hogen-Esch, T. E.; Thompson, M. E. J. Am. Chem. Soc. 2009, 125, 7796. 